\title{
THE Q ANGLE ANALYSIS, DURING RESISTANCE TRAINING, ON OPEN KINEMATICS CHAIN AND INTERMIDIATE CLOSED KINEMATICS CHAIN, THROUGH PHOTOGRAMETRY
}

\author{
MS. AYSLAN JORGE SANTOS DE ARAUJO \\ Faculdade de Aracaju (FACAR/UNIP/SE) \\ (Aracaju - Sergipe - Brasil) \\ E-mail: ayslanjorge@hotmail.com
}

\author{
DR. WALDERI MONTEIRO DA SILVA JUNIOR \\ Núcleo de Fisioterapia, Centro de Ciências Biológicas e da Saúde, \\ Universidade Federal de Sergipe \\ (Aracaju - Sergipe - Brasil) \\ E-mail:walderim@yahoo.com.br
}

\begin{abstract}
To examine the $Q$ angle, during the resistance training by "Leg Press 45" and the "extensor chair". I 4 female subjects practitioners gym carried out exercises at OKC and ICKC, ranging from $0^{\circ}$ to $90^{\circ}$ of flexion, where images were recorded each $10^{\circ}$. Through SAPO v.068, the $Q$ angles were measured; and conducted a T-test for independent samples with $p<0.05$. The resistance training should include muscle exercises in OKC and ICKC, with special attention to the last one, contradicting the view of some authors. The $Q$ angle, when compared to OKC and ICKC, changed with the increase of bending the knee for both knees to normal as the valgus, validating the combination of exercises in OKC and ICKC in muscle strengthening, for possible trend to the pathologic valgus.
\end{abstract}

KEYWORDS: Q Angle; Biomechanics; Resistance Training; Valgus. 


\section{INTRODUCTION}

The resistance training is the set of physical exercises performed in a way that has a voluntary muscle contraction. Thereby, it generates a force antagonistic to the extra corporis resistance applied. With the designation, resistance training, this is known as an ancient and universal practice that has developed, refined and improved as the scientific and technological advances make global dimensions. It is known also by weight training, strength training, resistance training or resistive training (JOVINE, 2006). The sciences: kinesiology, biomechanics and physiology, analyze, improve and promote adjustments to equipments and technical proposals for the training, agreeing with the objectivity and specificity of the work to be developed.

This training method is used to fitness, but it is necessary to give attention of the posture. There is not only a satisfactory performance, but also hurt prevention, during or after the activities period (BRACCIALLI; VILARTA, 2000). Therefore, the practitioner and the professional responsibility should look for a correct posture during the exercises (NETO JUNIOR; PASTRE; MONTEIRO, 2004). However, it is the professional responsibility to look of the individual postural deviations, as has predominantly valgus knees.

The valgus knee is a deviation in the coronal plane with overhead on lateral compartment, with a consequent increase in femorotibial angle of valgism and an obliquity of articulate interline medially. This overload causes biomechanical changes, occurring progressive loss of cartilage, subchondral bone and subsequent arthrosis, with capsuloligamentous stretching (INSALL, 1984). According to Fialho et al. (2007), the adoption of incorrect postures can cause a lot of problems such as injuries in muscle and tendons, physical fatigue, cramps, muscle pain and tremors.

The "Extensor Chair" and the "Leg Press 45" are two kits used in resisted training sessions and directly involve the knee joint. The first works in Open Kinematics Chain (OKC) and the second in the Intermediate Closed Kinematics Chain (ICKC). The difference between them is in the muscular action. In open chains the muscles contract to move segments with distal ends that move free in the space and on the extremities. In the kinematics chain movement on "Leg Press $45^{\circ}$, the work is performed in intermediate closed kinematic chain because it is applied a resistance at the end member, limiting the movement to set a direction, with the both displacement (CARPENTER, 2005).

The $\mathrm{Q}$ angle or quadriceps angle is formed by the intersection of two lines, one that involves the ASIS (anterior superior iliac spine) and patella center, and another that involves the patella center and the anterior tibial tuberosity. This angle is the overhead in valgus that acts on the knee and, when excessive, may create complications in the joint (BELCHIOR et al. 2006). 
According to Sacco et al. (2007), the angle can be measured using a universal goniometer, a method widely used at physiotherapeutic evaluations, but can also be measured by $x$-rays or magnetic resonance imaging. Besides these methods, the software of posture evaluation can be used through technological resources such as photography and film.

The photogrammetry or cinemetry uses photographic images and films to analyze the movement, so is a good option for those who aims to work with postural evaluations and biomechanical movements' analysis. This tool is very viable, because it has affordable price, good accuracy and is not invasive (CARREGARO; SILVA; GIL COURY, 2007).

Another important tool to be used for posture analysis is the SAPO v.068 of July/2007. It works with pictures analysis in which there is a defined protocol, but the program allows the user to create own protocols through certain anatomical points. The SAPO v.068 is distributed under the GNU General Public License as published by Free Software Foundation, version 2, June/I 99I . According to Sacco et al. (2007) is also advisable to use the goniometer to help, if the goal is measuring angles.

Considering the data above, this study aims, through a clinical trial to analyze the quadriceps angle, during the resistance training on "Leg Press $45^{\circ}$ " and "Extensor Chair", both weight training equipment. The first, working on intermediate closed kinematic chain system, and the second in open kinematic chain.

\section{METODOLOGY}

\section{CASUISTIC}

This test was conducted with a group composed of I 4 female subjects with mean age $29.3 \pm 7.5$ years, practitioners of resistance training, all volunteers, residents in the city of São Domingos / SE. All were in advance, informed and educated about the conduct and purpose of the study, and signed a term of free and informed consent, which guaranteed the privacy of personal information. This study also met the standards for the conduct of research in humans, resolution 196/96 of the Health National Council of 10 October 1996.

As factors of social, male individuals were adopted individuals; the age under I 8 or above 40 years, who were not practitioners of endurance training, which had limited the knee joint, who complained of pain before or during the course of the exercises on Extensor Chair or on the "Leg Press 45"; those who did not use the two devices in their training sessions, and individuals not trained for three to five times a week at an average of two hours per day. 
Data collection was in the Academy "Conexão Física", located at José Bernardino Street, s/n, Santos Domingos - SE.

\section{IST STAGE (INTRODUCTION AND FAMILIARIZATION):}

The first part of our meeting was an informal conversation between evaluators and evaluated. It was possible to share with the evaluated the relevant information, such as: objectives, justification, the whole procedure would be used during data collection, and all questions that, perhaps, came with the explanation, such as use of images, approval of the study by the Ethics Committee and safety of evaluated for the procedure. After the debate, was presented to group the Term of Free and Informed Consent, available on the web site of the Tiradentes University - SE, allowing participation in the study on a voluntary basis, in accordance with the terms of Resolution 196/96 of 10 October 1996, the Health National Council, under the protocol No 020808.

\section{ND STAGE (MARKING POINTS):}

The individuals were placed in the standing position and the evaluator was positioned in front of the individual, then using a dermographic pencil were marked the following points:

- Anterior Superior lliac Spine (ASIS): the evaluator was previously positioned to assess and support the region between the thumb and forefinger of his hands in the iliac crests evaluated, and with the tip of thumbs down was directed to locate and mark - them with the pen;

- Center of the Patella: It was located on the apex and the medial and lateral margins of the patella. With the help of an anthropometrical tape, accuracy of I mm, inextensible, glass fiber, Sanny brand, was marked the midpoint between the base and apex, and lateral and medial margins, identifying thus the central point of the patella.

- Anterior Tuberosity of the Tibia: for marking that point was taken as a reference the first prominent bone found below the patella in the anterior portion of the tibia.

\section{RD STAGE (SETTING OF POLYSTYRENE BALLS):}

With the points already marked, the white polystyrene balls of $25 \mathrm{~mm}$ in diameter were fixed to the anatomical points with the aid of a double-sided adhesive tape, $12 \mathrm{~mm}$ thick, and Eurocel mark. 
The individual was instructed to remain standing in order to stay in a comfortable position, with the back facing to the wall. It was not considered standard the removal of the feet, because at that time the goal was to verify the usual stance that individual, described in the protocol SAPo $\vee 0.68$.

By using a digital camera with resolution of 6.0 Mega Pixels, KENON brand, positioned through a medium in height between the iliac spine and the anterior tuberosity of the tibia and with a distance of 2 meters of the individual, which favored a good centralization points in the study, and therefore a good view of them in the picture.

In Fig. I, is presented a picture of an individual in the standing position, after the completion of the 4th stage.

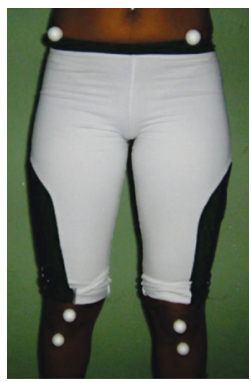

Figura I. Individual in the standing position

\section{TH STAGE (EXTENSOR CHAIR):}

The individual was placed in the unit so that the axis of the lever coincide with the line of the knee, adjusting the backrest to have a full support of the trunk, and put the tip of the lever of the apparatus to the front of the articulation tibia tarsal. The apparatus used in this assessment is the mark METALTEC and has at least $5 \mathrm{~kg}$ load, this is used during the test. The device consists of pulleys fixed, but it is not merit of this study consider the actual value of the applied load. In Fig. 2, you can view the original position in the extensor chair.

With the aid of a universal goniometer CARCI brand, with $2^{\circ}$ (two degrees) of error, was measured the flexion angle of knee. The initial angle of 90 degrees was considered and there was a record front of anatomical points, every $10^{\circ}$ of extension ends at the point $0^{\circ}$.

The image was captured by the camera that was attached to a support (tripod), a distance of I $\mathrm{m}$ (one meter) of assessed, with $1.5 \mathrm{~m}$ in height and an 
inclination of $45^{\circ}$ to the ground, pointing to the assessed. After the capture of the image, recording the name of record storage in the camera and the corresponding angle were performed.

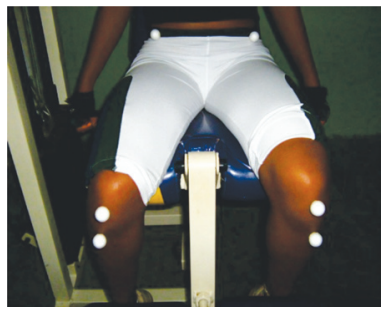

Figura 2. Individual on the Extensor Chair

\section{TH STEP (INTERVAL / REPOSE):}

Recovery time of the individual consisted of three minutes for the individual to make a lightweight hydration, their physiological needs and return your body to begin the next phase (DANTAS, 1998).

\section{TH STAGE (LEG PRESS 45):}

In this session, the individual is positioned in the apparatus so that the bole and hip are supported in the backrest and the feet are supported on a mobile platform, where there is also a bar to the placing of load, but this study is not used pack, considering only the support as loading, despicable. For the positioning of the feet, it took into account the removal usual for the individual, since it is near the middle region between the limits above, below and the lateral support. The apparatus used in this evaluation is the METALTEC brand and it has not pulleys as above. The system of loads it is through rings placed on a platform, where the feet are supported throughout the movement. In Fig. 3, you can check the starting position in the "Leg Press 45․"

With the aid of a universal goniometer of CARCl brand, the flexion angle of knee was measured, as well as the extensor chair, considering the axis of the goniometer aligned with the axis of the knee and one of the ends fixed in the middle portion of the thigh, the other, mobile, to delimit the range of motion of the leg of the individual. The initial angle was considered $0^{\circ}$ and there was a front record of anatomical points, every $10^{\circ}$ of flexion, ending at $90^{\circ}$ point.

The image was captured by the camera that was attached to the tripod, as the back of the unit, opposite the platform at a height of $\mathrm{Im}$ and an inclination of $45^{\circ}$ 
to the ground, pointing to the individual. After taking the picture, the name of the record storage chamber and the corresponding angle were recorded.

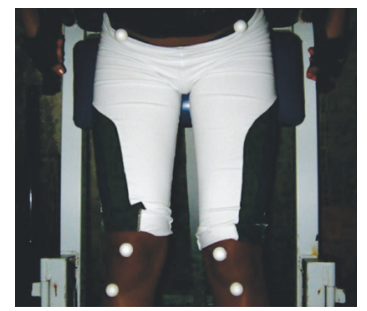

Figura 3. Individual on the Leg Press $45^{\circ}$

\section{TH STAGE (DATA ARCHIVING AND PROCESSING OF IMAGES):}

The images were transferred from the camera to a computer setting: Intel Core 2 Duo processor, I. $83 \mathrm{GHz}, 2$ GB RAM, through connection "Bluetooth." In the microcomputer, the photos taken in the "Leg Press $45^{\circ}$ " received a spin of $180^{\circ}$, so they could be examined by the postural evaluation software, and organized into folders sorted by equipment used, extensor chair and "Leg Press 45".

\section{TH STAGE (POSTURAL ANALYSIS):}

With the help of the postural evaluation software, SAPo v.068, a protocol called "USER I "was created, using three points, for the measurement of the angle "Q", these are: the anterior superior iliac spine, the center Patella and the anterior tuberosity of the tibia. The program measured the value of the angle to the knees, right and left of each captured image, and after, recorded these values in a table.

The data allowed the separation and classification of the knees to be worked, and then both groups were separated by apparatus, these are: normal knees and valgus knees, which allowed the necessary statistical analysis.

\section{RESULTS AND DISCUSSION}

Considering the $\mathrm{Q}$ angle equal to $0^{\circ}$, or neutral, as normal alignment between the three studied anatomical points, the lateral angle of the knee of $170^{\circ}-175^{\circ}$, it has positive values for those representatives of valgus knee and negative values for those Representatives of normal knees.

The $T$ test for independent samples $(p<0.05)$ totaled three combinations: normal and valgus, both in OKC, normal and valgus, both in ICKC; normal OKC 
and ICKC. In the relationship between the angles of the knee in both normal and Valgus on OKC, there was significant difference of values of $Q$ angle measured between the groups only to 0 degree $(p=0,0 \mid 5)$, I 0 degrees $(p=0,04 I)$ and 80 degrees ( $p=0,043)$ of flexion knee. However, it is necessary to look throughout the execution of moving the valgus knees, statistically, remained within a range not pathological again showing signs of valgism from 10 degrees of flexion. These data are represented in Table I.

Table I. Normal vs. Valgus on OKC

\begin{tabular}{|c|c|c|c|c|c|c|c|c|c|c|}
\hline & $\begin{array}{c}90^{\circ} \\
(\mu \neq \alpha)\end{array}$ & $\begin{array}{c}80^{\circ} \\
(\mu \neq \alpha)\end{array}$ & $\begin{array}{c}70^{\circ} \\
(\mu \neq \alpha)\end{array}$ & $\begin{array}{c}60^{\circ} \\
(\mu \neq \alpha)\end{array}$ & $\begin{array}{c}50^{\circ} \\
(\mu \neq \alpha)\end{array}$ & $\begin{array}{c}40^{\circ} \\
(\mu \neq \alpha)\end{array}$ & $\begin{array}{c}30^{\circ} \\
(\mu \neq \alpha)\end{array}$ & $\begin{array}{c}20^{\circ} \\
(\mu \neq \alpha)\end{array}$ & $\begin{array}{c}10^{\circ} \\
(\mu \neq \alpha)\end{array}$ & $\begin{array}{c}0^{\circ} \\
(\mu \neq \alpha)\end{array}$ \\
\hline $\begin{array}{c}\text { Norma } \\
\text { (OKC)- } \\
\left({ }^{*}\right)\end{array}$ & $-15,2 \neq 10,7$ & $-12,7 \neq 8,1$ & $-9, \mid \neq 8,3$ & $-4,9 \neq 7,1$ & $-2,3 \neq 9,2$ & $0,5 \neq 6,2$ & $4,3 \neq 6,9$ & $7,1 \neq 6,5$ & $10,0 \neq 7,9$ & $13,7 \neq 8,0$ \\
\hline $\begin{array}{c}\text { Valgus } \\
\text { (OKC)- } \\
\left(^{*}\right)\end{array}$ & $-10,4 \neq 10,6$ & $-6,2 \neq 8,1$ & $-3,5 \neq 7,7$ & $-0,6 \neq 6,6$ & $2,7 \neq 5,4$ & $4,4 \neq 7,0$ & $8,3 \neq 5,9$ & $10,7 \neq 4,6$ & $15,9 \neq 6,6$ & $22,0 \neq 8,7$ \\
\hline$\rho$ & 0,236 & 0,043 & 0,075 & 0,112 & 0,087 & 0,131 & 0,114 & 0,110 & 0,041 & 0,015 \\
\hline
\end{tabular}

It is important not to move to a zone of pathologic valgus, or not suffer a injuring deviation, as shows a possibility of working the femoral quadriceps without compromising the articulation of these individuals, reducing capsule stress and, consequently, the possibility of ligament injuries after sometime, making the work more efficient and less painful. (ALBUQUERQUE et al. 2003).

In the relationship between Normal and Valgus, both in ICKC, there was no significant difference for the values of the $\mathrm{Q}$ angle, and the normal knees took valgus characteristics in the first two angles of flexion. The normal knees had their degrees Q increased as the extension was happening. The same happens to the valgus knee, it probably occurs because it is the same kinematic chain, and the consequent use of the same muscle groups. It is also perceived that in valgus this variation in amplitude enough to be smaller in relation to normal, as shown in Table 2. 
Table 2. Normal vs. Valgus on ICKC

\begin{tabular}{c|llllllllll}
\hline & $90^{\circ}$ & $80^{\circ}$ & $70^{\circ}$ & $60^{\circ}$ & $50^{\circ}$ & $40^{\circ}$ & $30^{\circ}$ & $20^{\circ}$ & $10^{\circ}$ & $0^{\circ}$ \\
& $(\mu \neq \alpha)$ & $(\mu \neq \alpha)$ & $(\mu \neq \alpha)$ & $(\mu \neq \alpha)$ & $(\mu \neq \alpha)$ & $(\mu \neq \alpha)$ & $(\mu \neq \alpha)$ & $(\mu \neq \alpha)$ & $(\mu \neq \alpha)$ & $(\mu \neq \alpha)$ \\
\hline $\begin{array}{c}\text { Normal } \\
\text { (ICKC)- } \\
\left(^{*}\right)\end{array}$ & $8,3 \neq 20,7$ & $9,2 \neq 14,5$ & $9,3 \neq 11,5$ & $9,5 \neq 11,8$ & $11,5 \neq 9,8$ & $11,1 \neq 9,2$ & $12,7 \neq 9,7$ & $14,6 \neq 8,9$ & $15,2 \neq 8,4$ & $16,4 \neq 8,8$ \\
$\begin{array}{c}\text { Valgus } \\
\text { (ICKC)- } \\
(*)\end{array}$ & $15,9 \neq 13,5$ & $14,7 \neq 13,0$ & $15,0 \neq 11,3$ & $16,3 \neq 10,3$ & $16,8 \neq 9,3$ & $16,4 \neq 8,4$ & $18,8 \neq 6,4$ & $19,6 \neq 5,1$ & $19,7 \neq 4,4$ & $21,4 \neq 5,5$ \\
$\rho$ & 0,260 & 0,299 & 0,197 & 0,119 & 0,149 & 0,119 & 0,061 & 0,082 & 0,087 & 0,088 \\
\hline
\end{tabular}

Tang et al. (200 I) to conduct a study of the activation of the vastus medialis oblique (VMO) and vastus lateralis $(\mathrm{VL})$, by electromyography, concluded that in the closed kinematic chain VMO had greater activation at 60 degrees of flexion, and therefore was expected sharp valgism to this angle, but this study showed a tendency to valgism until the angle $0^{\circ}$ for both categories. Beyond the valgism, the difference between the normal knees and valgus had increased as the flexion decreased, possibly by growing the activation of the $\mathrm{VMO}$ in the final angles, reversing partially Tang et al. (200I).

The normal knees into a zone of valgism at angles of 0 and 10 degrees of flexion, the valgus knee has remained during the entire movement within the zone of valgism $\left(\mathrm{Q}<15^{\circ}\right)$ decreased proportionally as the flexion was realized, which in OKC the angular range was higher than found in ICKC.

Table 3. Normal (OKC) vs. Normal (ICKC)

\begin{tabular}{|c|c|c|c|c|c|c|c|c|c|c|}
\hline & $\begin{array}{l}90^{\circ} \\
(\mu \neq \alpha)\end{array}$ & $\begin{array}{l}80^{\circ} \\
(\mu \neq \alpha)\end{array}$ & $\begin{array}{l}70^{\circ} \\
(\mu \neq \alpha)\end{array}$ & $\begin{array}{l}60^{\circ} \\
(\mu \neq \alpha)\end{array}$ & $\begin{array}{l}50^{\circ} \\
(\mu \neq \alpha)\end{array}$ & $\begin{array}{l}40^{\circ} \\
(\mu \neq \alpha)\end{array}$ & $\begin{array}{l}30^{\circ} \\
(\mu \neq \alpha)\end{array}$ & $\begin{array}{l}20^{\circ} \\
(\mu \neq \alpha)\end{array}$ & $\begin{array}{l}10^{\circ} \\
(\mu \neq \alpha)\end{array}$ & $\begin{array}{l}0^{\circ} \\
(\mu \neq \alpha)\end{array}$ \\
\hline $\begin{array}{c}\text { Normal } \\
(\text { CCA ) - } \\
\left({ }^{\circ}\right)\end{array}$ & $-15,26 \neq 10,7$ & $-\mid 2,7 \neq 8,1$ & $-9, \mid \neq 8,3$ & $-4,9 \neq 7,1$ & $-2,3 \neq 9,2$ & $0,5 \neq 6,2$ & $4,3^{\prime} 6,9$ & $7,1 \neq 6,5$ & $10,0 \neq 7,9$ & $13,7 \neq 8,0$ \\
\hline $\begin{array}{c}\text { Normal } \\
\text { (CCFI) - } \\
\left({ }^{\circ}\right)\end{array}$ & $8,3 \neq 20,7$ & $9,2 \neq 14,5$ & $9,3 \neq 11,5$ & $9,5 \neq 11,8$ & $11,5 \neq 9,8$ & $|I| \neq 9,2$, & $12,7 \neq 9,7$ & $14,6 \neq 8,9$ & $15,2 \neq 8,4$ & $16,4 \neq 8,8$ \\
\hline$\rho$ & 0,001 & 0,000 & 0,000 & 0,001 & 0,001 & 0,001 & 0,014 & 0,017 & 0,103 & 0,405 \\
\hline
\end{tabular}

In the relationship between Valgus in OKC and Normals in ICKC, observed in Table 03, significant differences were found for the angles from 20 to 90 degrees of flexion. To 10 degrees $(p=0103)$ and 0 degree $(p=405)$ there was no significant difference in the values found for the $Q$ angle. It is important to note that the angles increase in $\mathrm{OKC}$, continuously from $90^{\circ}$ to $0^{\circ}$, in ICKC is also a gradual increase of $90^{\circ}$ to $0^{\circ}$, but between $40^{\circ}$ and $50^{\circ}$ there was a light variance of the trend. 
The exercise in open kinematic chain (OKC) provoked an angular variation within the normal range for about $80 \%$ of the degrees of studied flexion, while the exercise in intermediate closed kinematic chain (ICKC) caused a greater deviation in measured angles, thus showing that the exercises in OKC can be given to subjects with normal knees, but is not discarded the possibility of realization exercises in ICKC, where respected load limits and amplitudes according to the clinical specificity of the individual. This shows that the work of the two chains of different exercises on the actions of the forces active in the knee joint, and that in all cases studied, the $\mathrm{Q}$ angle was presented to a more biased to valgism in exercises in the ICKC that in OCK, even for the normal knee, which could be damaging the joint by excessive pressure in the region of the medial joint capsule. However, it is not discarded the possibility of using exercises in ICKC.

Moreover, various studies contradict this statement, as the studies of Stiene et al. (1996), which show that the exercises of ICKC are more efficient than those of OKC in functional rehabilitation of patients with impaired patellofemoral. Additionally, some authors have suggested that exercises in closed kinetic chain (CKC) are safer than open kinetic chain exercises in (OKC) for subjects with patellofemoral pain syndrome (PFPS), as exercises in CKC produce less stress on the patellofemoral joint during the functional range of motion so that PFPS patients better tolerate CKC in the exercises, and consequently produce better functional outcomes after a rehabilitation program (STEINKAMP et al. 1993; HUNGERFORD; BARRY, 1979). That stress can be considered as not maintaining the dimensions and patterns of the knee joint, but it is perceived by the results presented, that the exercises in ICKC cause a change in $\mathrm{Q}$ angle, which leads to increased instability articulate, compression capsule, ligamentous laxity, and PFPS.

Already Mikkelsen, Werner and Eriksson (2000), in patients after reconstruction of anterior cruciate ligament (ACL) observed a faster recovery, combining CKC and OKC, as compared with isolated exercises in CKC. Thus, the combination of CKC and $\mathrm{OKC}$ can be used in rehabilitation after $\mathrm{ACL}$ reconstruction without causing excessive tension at the ligament and stress in the joint knee.

The combination of exercises in OKC and ICKC for both categories is considered favorable because they are being used to get up from a sitting position, or to walk, run, climb a ladder, directing, accommodate themselves to a bed, a sofa, a bathroom, finally, in all situations of daily life. Therefore, the muscle training should cover the exercises in both OKC and in ICKC, with the latter should be a special focus on the range of motion at the expense of preservation articulate, more specifically in the maintenance of the $\mathrm{Q}$ angle, thus avoiding possible injuries and joint pain. 


\section{CONCLUSION}

The study showed that the $Q$ angle, when compared to exercises of open and intermediate closed kinematic chain, has changed as the movement of knee flexion was realized for both knees, normal and valgus. Thus, it applies a combination of exercises in the OKC and ICKC during muscle strengthening, taking due care with a tendency to pathologic valgus determined by $\mathrm{Q}$ angle.

\section{Análise do ângulo $Q$, durante o treinamento resistido, em cadeia cinemática aberta e cadeia cinemática fechada intermediária através de fotomiografia}

RESUMO: Analisar o ângulo $Q$, durante o treinamento resistido no "Leg Press $45^{\circ}$ " e na "Cadeira Extensora". I 4 indivíduos do gênero feminino praticantes de treinamento resistido executaram um exercício em CCA e um em CCFI, variando de 0 a $90^{\circ}$ de flexão onde eram registradas imagens frontais a cada $10^{\circ}$ de amplitude. Através do SAPo v.068, foram medidos os Ângulos $Q$ e com as médias por grupos, realizado um Teste t para amostras independentes com $p<0,05$. O ângulo $Q$, quando comparado em CCA e CCFI, alterou-se com o aumento da flexão do joelho, tanto para os joelhos normais quanto para os valgos, então é válida a combinação de exercícios em CCA e CCFI no fortalecimento muscular, tendo o devido cuidado com a tendência ao valgismo patológico determinada pelo ângulo $Q$.

PALAVRAS-CHAVES: Ângulo Q; biomecânica; treinamento resistido; valgo.

\section{Análisis del ángulo Q, durante el entrenamiento de resistencia en cadena cinética abierta y cadena cinemática cerrada intermedia mediante Microfotografía}

RESUMEN: Analizar el ángulo Q, durante el entrenamiento de resistencia en el "Leg Press $45^{\circ}$ " y la "máquina de extensión de la pierna". I 4 sujetos de sexo femenino realizó un ejercicio de entrenamiento de resistencia en CCA y una en CCCl, que van desde 0 a $90^{\circ}$ frente a donde las imágenes se registraron cada 10 grados de amplitud. A través de SAPO v.068, ángulos $Q$ fueron medidos y las medias por grupos, llevó a cabo un test t para muestras independientes con $p<0,05$. El ángulo $Q$, cuando comparado en CCA y CCCl, cambiado con el aumento de la flexión de rodilla de ambas rodillas en valgo y para las normales. Es válida una combinación de ejercicios en CCA y CCCl el fortalecimiento del músculo, teniendo el debido cuidado con la tendencia a valgus patológico determinada por el ángulo $Q$.

PALABRAS CLAVE: Ángulo Q; la biomecánica; entrenamiento de resistencia; valgo. 


\section{REFERENCES}

ALBUQUERQUE, R. F. M. et al. Valgus osteotomy of the tibia with a Puddu plate combined with anterior cruciate ligament reconstruction. Acta Ortopédica Brasileira, São Paulo, v. I I, n. I, p. II-16, jan. 2003

BELCHIOR, A. C. G.; ARAKAKI, J. C.; BEVILAQUA-GROSSI, D.; REIS, F. A.; CARVALHO, P. T. C. Efeitos na medida do ângulo $Q$ com a contração isométrica voluntária máxima do músculo quadricipital. Revista Brasileira de Medicina do Esporte, Niterói, v. I2, n. I, p. 6- I0, jan./fev. 2006

BRACCIALLI, L. M. P.; VILARTA, R. Aspectos a serem considerados na elaboração de programas de prevenção e orientação de problemas posturais. Revista Paulista de Educação Física, São Paulo, v. |4, p. |59-7|, fev./dez. 2000

CARPENTER, C. S. Biomecânica. Rio de Janeiro: Sprint, 2005

CARREGARO, R. L.; SILVA, L. C. C. B.; GIL COURY, H. J. C. Comparison between two clinical tests for the evaluation of posterior thigh muscles flexibility. Revista Brasileira de Fisioterapia, São Carlos, v. II, n. 2, p. 125-130, mar./apr. 2007

DANTAS, E. H. M. A prática da preparação física. 4. ed. Rio de Janeiro: Shape, 1998

FIALHO, P. B.; SOUZA, A. P.; MINETTE, L. J.; SILVA, J. C. Avaliação ergonômica de cadeiras residenciais fabricadas no polo moveleiro de Ubá, MG. Revista Árvore, Viçosa, vol. 31 , n. 5 , p. 887-896, out. 2007

HUNGERFORD, D. S.; BARRY, M. Biomechanics of the patellofemoral joint. Clinical Orthopedics and Related Research, New York, vol. I44, p. 9-15, out. 1979

INSALL, J. N. "Osteotomy", In: INSALL. Surgery of the knee. New York: Churchill Livingstone, 1984. p. $551-585$

JOVINE, M. S. Efeito do treinamento resistido sobre a osteoporose após a menopausa: estudo de atualização. Revista Brasileira de Epidemiologia, São Paulo, vol. 9, n. 4, p. 493-505, dec. 2006

MIKKELSEN, C.; WERNER, S.; ERIKSSON, E. Closed kinetic chain alone compared to combined open and closed kinetic chain exercises for quadriceps strengthening after anterior cruciate ligament reconstruction with respect to return to sports: a prospective matched follow-up study. Knee Surgery, Sports Traumatology, Arthroscopy, Heidelberg, vol. 8, n. 6, p. 337-342, dec. 2000

NETO JUNIOR, J.; PASTRE, C. M.; MONTEIRO, H. L. Alterações posturais em atletas brasileiros do sexo masculino que participaram de provas de potência muscular em competições internacionais. Revista Brasileira de Medicina do Esporte, v. 10, n. 3, p. 195- 198, mai./jun. 2004 
SACCO, I. C. N. et al. Confiabilidade da fotogrametria em relação a goniometria para avaliação postural de membros inferiores. Revista Brasileira de Fisioterapia, São Carlos, v. I I , n. 5, p. 4II-4I7, set./out. 2007

STEINKAMP, L. A. et al. Biomechanical considerations in patellofemoral joint rehabilitation. American Journal of Sports Medicine, Batilmore, vol. 21 , n. 3, p. 438-444, mai./jun. 1993

STIENE, H. A. et al. A comparison of closed kinetic chain and isokinetic joint isolation exercise in patients with patellofemoral dysfunction. Journal Orthopaedic Sports Physical Therapy, Washington, vol. 24, n. 3, p. 136-142, set. 1996

TANG, S. F. T. et al. Vastus medialis obliquus and vastus lateralis activity in open and closed kinetic chain exercise in patients with patellofemoral pain syndrome: an electromyographic study. Archives Physical Medicine and Rehabilitation, Chicago, vol. 82, p. I44I-5, out. 200 I

Recebido em: I I jul. 2012 Aprovado em: 30 ago. 2013 Endereço para correspondência: Ayslan Jorge Santos de Araujo Rua G, 0 I . Condomínio Solar Mon Jardin. Bloco Íris 505 Conjunto Santa Lúcia - Bairro Jabotiana CEP: 49I00-000 São Cristóvão - SE 
